\title{
Effect of Auxins and Associated Metabolic Changes on Cuttings of Hybrid Aspen
}

\author{
Shao Peng Yan ${ }^{1}$, Rui Hua Yang ${ }^{2}$, Fang Wang ${ }^{1}$, Li Na Sun ${ }^{1}$ and Xing Shun Song ${ }^{1,3, *}$ \\ 1 Department of Genetics, College of Life Science, Northeast Forestry University, Harbin 150040, China; \\ yanshaopeng@nefu.edu.cn (S.P.Y.); wangfang5992@163.com (F.W.); s1991103@163.com (L.N.S.) \\ 2 Department of Horticulture, Heilongjiang Academy of Agricultural Science, Harbin 150000, China; \\ yrh_ray@126.com \\ 3 State Key Laboratory of Tree Genetics and Breeding (Northeast Forestry University), Harbin 150040, China \\ * Correspondence: xssong@nefu.edu.cn; Tel.: +86-0451-8219-1755
}

Academic Editors: Sune Linder and Timothy A. Martin

Received: 26 January 2017; Accepted: 4 April 2017; Published: 10 April 2017

\begin{abstract}
In the present study, an attempt was made to induce rooting from single-node cuttings of hybrid aspen (Populus tremula L. $\times$ P. tremuloides Michx.) with different concentrations of Indole-3-acetic acid (IAA), Indole-3-Butytric acid (IBA) and 1-Naphthylacetic acid (NAA). Among the three auxins used, $0.54 \mathrm{mM}$ NAA showed more effective induction on rooting as compared to IAA and IBA at the whole level. Thereafter, $0.54 \mathrm{mM}$ NAA was used further for the anatomical and biochemical investigation. The results showed that it took 12 days from the differentiation of primordium to the appearance of young adventitious roots under NAA application. It was found that endogenous IAA, Zeatin riboside (ZR) and Gibberellic Acid (GA3) levels increased, but Abscisic acid (ABA) decreased in cuttings with NAA treatment. In contrast to the endogenous IAA level, NAA resulted in a decrease in IAA-oxidase (IAAO) activity. Similarly, the decreased peroxidase (POD) activity, consistent with down-regulation of expressed levels of POD1 and POD2, was observed in NAA-treated cuttings. Moreover, NAA resulted in a higher activity in polyphenol oxidase (PPO) compared with control cuttings. Collectively, the study highlighted that 0.54 mM NAA is efficient on rooting in hybrid aspen, and its effect on metabolic changes during rooting was discussed, which can provide valuable information for propagating hybrid aspen.
\end{abstract}

Keywords: auxin; cutting; hybrid aspen; rooting

\section{Introduction}

One of the most important challenges at present is the need to replace fossil fuel-based energy sources with renewable energy, such as woody biomass, in order to sequester atmospheric $\mathrm{CO}_{2}[1,2]$. One way to satisfy the increasing demand for woody biomass is through the establishment of short-rotation forest plantations [3]. For this purpose, hybrid aspen (Populus tremula L. $\times$ P. tremuloides Michx.), a cross between the European aspen (P. tremula L.) and its North American counterpart, trembling aspen (P. tremuloides Michx.), has proven to be one of the most promising species for intensive pulp and biomass production due to its fast growth, cold resistance and pathogen resistance [4-6].

Although it is difficult to root hybrid aspen, propagation through cuttings is the most commonly used asexual method. The successful establishment from stem cuttings, however, depends upon many factors, such as seasonal and age variation, portion and diameter of stem, growing media, moisture level, nutrient status and temperature, etc. [7]. In particular, plant growth regulatory hormones or 'auxins' play a vital role in influencing the sprouting and survival of stem cuttings. Adventitious rooting (AR) is a complex developmental process that can be stimulated by exogenously-applied auxins [8], the effect of which is to increase initiation of the root primordium and growth via cell 
division [9]. In addition, the interdependent physiological stages of the rooting process are also associated with changes in endogenous auxin concentrations [10]. Some endogenous factors, hormones and/or hormonal balance, tissue maturity, expression of specific regulatory genes, etc., have also been recognized as fundamental factors in this regeneration scenario [11-16]. However, the combined effects of auxin type, auxin concentration, and the accompanying biochemical changes on rooting of hybrid aspen cuttings are not well studied. Moreover, the knowledge of the intricate signaling network participated in by these factors during AR formation in cuttings is fragmentary [17]. The aim of the present study is to establish the rooting efficiency from cuttings of hybrid aspen under controlled conditions, to gain an insight into the process of redifferentiation by anatomical observation, and to investigate the biochemical changes, as well as the related gene expression during AR development.

\section{Materials and Methods}

\subsection{Preparation of Stem Cuttings}

Mature stem cuttings of hybrid aspen (Populus tremula L. $\times$ P. tremuloides Michx.) were collected in the experimental greenhouse in Northeast Forestry University. The leaves and shoot apices were excised and uniform leafless semi-hard wood cuttings $(2-3 \mathrm{~cm}$ long and $0.5-1 \mathrm{~cm}$ diameter) comprising 1 node were prepared. The cuttings were dipped in distilled water for $10 \mathrm{~min}$, and subsequently treated with root-promoting auxins at the basal end. The cuttings received distilled water (control) or treatments of IBA, IAA and NAA individually at different concentrations ranging from $100-500 \mathrm{mg} \cdot \mathrm{L}^{-1}$, respectively, for a maximum of $1 \mathrm{~h}$ duration to determine the rooting capacity. Different combinations of the above rooting hormones were also tested to see any possible synergistic effects in promoting the rooting ability from the stem cuttings. Cuttings raised in a nursery bed were also used as source material for studying the effect of AR and effect of juveniles treated with the best responding concentration. The top (apical) cut ends of the treated cuttings were sealed with paraffin wax to reduce water loss. The nursery bed was incubated in a controlled growth chamber $\left(28 \pm 2{ }^{\circ} \mathrm{C}\right.$ and $80 \%$ relative humidity). Cuttings were harvested after 3, 6, 9, 12 and 15 days for anatomical, physiological and biochemical analysis, as well as the expression analysis of genes. Rooting percentage, number of roots per cutting, and root length were recorded from cuttings after 3 weeks of growth in the nursery bed.

\subsection{Anatomical Procedure}

Three cuttings of each time point of treatment were investigated, wherein the basal $1 \mathrm{~cm}$ of the cuttings (including the slanted cut) were removed and fixed for two days in formalin:alcohol:glacial acetic acid (FAA) solution $(1: 9: 1 ; v / v / v)$ using $70 \%(v / v)$ ethanol in distilled water, after which they were dehydrated using a series of $30 \%, 50 \%, 70 \%$ and $100 \%(2 \times)$ ethanol, each for $30 \mathrm{~min}$. The ethanol was substituted by means of a series of $30 \%, 50 \%, 70 \%$ and $100 \%(2 \times)$ xylol, each for $30 \mathrm{~min}$, followed by infiltration of wax [18]. Embedded sections were transverse sectioned at $8 \mu \mathrm{m}$ thickness and transferred onto glass slides. The slides were dipped twice in xylene for $5 \mathrm{~min}$ each and in ethanol for $5 \mathrm{~min}$. The slides were then air dried and dipped in 1\% safranin for $15 \mathrm{~min}$, rinsed three times in deionized water to remove excess stain, dipped in $0.75 \%$ malachite green solution (with $5 \%$ acetic acid and $8.5 \%$ glycerol) for $15 \mathrm{~s}$, and again rinsed three times in deionized water. Sections were then dried and mounted on slides, stained with safranin and counter stained with fast green, and photographed using a digital microscope (Axioskop, Zeiss, Germany).

\subsection{Assay of Endogenous Hormones}

Frozen tissue was ground with a mortar and pestle and hormones were extracted in $80 \%$ methanol. Samples were centrifuged at $10,000 \times g$ for $15 \mathrm{~min}$ at $4{ }^{\circ} \mathrm{C}$. The supernatant was collected and immediately applied to a pre-equilibrated C18 Sep-Pak cartridge (Millipore (Waters), Watford, UK), which was washed with $80 \%$ methanol solution and eluted with methanol:acetic acid $(4: 1, v / v)$. 
The extracts were collected and dried under N2 [19].The mouse monoclonal antigens, antibodies against $\mathrm{ZR}$, IAA, $\mathrm{GA}_{3}$, and ABA, and IgG-horseradish peroxidase in ELISA, were purchased from the Phytohormones Research Institute (China Agricultural University, Beijing, China). ELISA was performed on a 96-well microtitration plate. Each well on the plate was coated with $100 \mu \mathrm{L}$ coating buffer containing antigens against the hormones. The coated plates were incubated for $4 \mathrm{~h}$ at $37^{\circ} \mathrm{C}$ for $\mathrm{ZR}, \mathrm{GA}_{3}$, and $\mathrm{ABA}$, and overnight at $4{ }^{\circ} \mathrm{C}$ for IAA, and then kept at room temperature for $30 \mathrm{~min}$. After washing four times with PBS + Tween 20 buffer (pH 7.4), each well was filled with $50 \mu \mathrm{L}$ of either extracts or $\mathrm{ZR}$, IAA, $\mathrm{GA}_{3}$, and ABA standards, and $50 \mu \mathrm{L}$ antibodies against $\mathrm{ZR}, \mathrm{IAA}, \mathrm{GA}_{3}$, and ABA, respectively. The plate was incubated for $3 \mathrm{~h}$ at $28^{\circ} \mathrm{C}$ for $\mathrm{ZR}, \mathrm{GA}_{3}, \mathrm{ABA}$, and overnight at $4{ }^{\circ} \mathrm{C}$ for IAA, and then washed as above. Then, $100 \mu \mathrm{L}$ of IgG-horseradish peroxidase was added to each well and incubated for $1 \mathrm{~h}$ at $30^{\circ} \mathrm{C}$. The plate was rinsed five times with the above PBS + Tween 20 buffer, and $100 \mu \mathrm{L}$ of color-appearing solution containing 0-phenylenediamine and $0.008 \%(v / v) \mathrm{H}_{2} \mathrm{O}_{2}$ was added to each well. The reaction progress was stopped by adding of $50 \mu \mathrm{L} 2 \mathrm{M} \mathrm{H}_{2} \mathrm{SO}_{4}$ per well. Color development in each well was detected using an ELISA Reader (Sunrise, Tecan, Switzerland) at optical density A490. The results are the means \pm SE of at least four replicates.

\subsection{IAA Oxidase (IAAO) Assay}

The reaction mixture was made by mixing the $0.2 \mathrm{~mL}$ enzyme extracts, $0.78 \mathrm{~mL}$ of $50 \mathrm{mM}$ potassium-phosphate buffer ( $\mathrm{pH}$ 6.0), $0.01 \mathrm{~mL}$ of $5 \mathrm{mM} \mathrm{MnCl}_{2}, 0.01 \mathrm{~mL}$ of $5 \mathrm{mM}$ 2,4-dichlorophenol and $0.02 \mathrm{~mL}$ of $2.5 \mathrm{~g} / \mathrm{L} \cdot \mathrm{IAA}$. Assays were conducted at $25 \pm 0.5^{\circ} \mathrm{C}$ for $30 \mathrm{~min}$. The Salkowski reagent $(2 \mathrm{~mL})$ was then added and the destruction of IAA was determined by measuring the absorbance at 535 after $30 \mathrm{~min}$ [20]. Each value was the mean of three replicates. IAAO activity is represented by the amount of IAA degraded $(\mu \mathrm{g})$ starting from $1 \mathrm{mg}$ initial protein in $1 \mathrm{~h}$.

\subsection{Polyphenol Oxidase (PPO) Assay}

Polyphenol-oxidase enzyme assay was made by using pyrogallol as the substrate [21]. The $1 \mathrm{~mL}$ reaction mixture contained $250 \mu \mathrm{L}$ of the enzyme extract and $0.1 \mathrm{M}$ phosphate buffer $(\mathrm{pH} 6.0)$. Each sample was aerated for $2 \mathrm{~min}$ in a small test tube followed by the addition of $0.2 \mathrm{M}$ catechol as the substrate. PPO activity was expressed as changes in absorbance at $420 \mathrm{~nm} \cdot \mathrm{min}^{-1} \cdot \mathrm{g}^{-1} \mathrm{FW}$.

\subsection{Peroxidase (POD) Assay}

The activity of POD was determined according to the method of Li et al. [21] based on the oxidation of guaiacol using $\mathrm{H}_{2} \mathrm{O}_{2}$. The reaction mixture was made by mixing $0.1 \mathrm{~mL}$ enzyme extract, $0.01 \mathrm{~mL}$ $20 \mathrm{mM}$ guaiacol, $0.1 \mathrm{~mL} 50 \mathrm{mM} \mathrm{H}_{2} \mathrm{O}_{2}$, and $0.76 \mathrm{~mL} 2.5 \mathrm{mM}$ 3,3-dimethylglutaric acid (3,3-DGA)-NaOH at $\mathrm{pH}$ 6.0. Peroxidase activity was determined spectrophotometrically by monitoring the formation of tetraguaiacol at $470 \mathrm{~nm}$ after $10 \mathrm{~min}$ incubation at $30 \pm 0.5^{\circ} \mathrm{C}$. Each value is the mean of three replicates.

\subsection{Quantification of PCR Products}

Total RNA was treated with DnaseI and reverse-transcribed using PrimeScript RT reagents Kit (Taraka, Dalian, China). Then, 20 ng of retrotranscribed RNA was amplified with the SYBR Premix Ex Taq Kit (Takara, Dalian, China). The thermal cycling conditions were 40 cycles of $95^{\circ} \mathrm{C}$ for $30 \mathrm{~s}$ for denaturation and $58^{\circ} \mathrm{C}$ for $30 \mathrm{~s}$ for annealing and extension. All reactions were run in triplicate by monitoring the dissociation curve to control the dimers. Hybrid aspen gene actin was used as a normalizer, and the relative expression levels of genes were presented by $2-\triangle \triangle C t(\triangle C t$ is the difference of $\mathrm{CT}$ between the actin and the target gene).

PCR reactions employed the following primers: POD1-F (AGAATCGGTTGTCTTGGCAGG-3), POD1-R (GGGATGAAAGCATTAGCAGCA); POD2-F (TAGCGGGGCTGATACTGTTGC), and POD2-R (ATTTCTCCATTGCTTCCTGTC-3), respectively. 


\subsection{Statistical Analysis}

Significant difference, wherever mentioned, among the data was accomplished by analysis of variance (ANOVA) at significance level of $p<0.05$, and mean separation was done using Student's $T$ Test using R software (Manugistics Inc., Rockville, MD, USA).

\section{Results}

\subsection{Effects of a Range of Auxin Types on Rooting of Hybrid Aspen}

In the present study, although all three auxins resulted in a significant induction of AR in hybrid aspen cuttings, there were significant differences $(p<0.05)$ under different auxins with different concentrations. The cuttings treated with $0.54 \mathrm{mM}$ NAA showed maximum percentage of rooting and maximum number of roots per cutting (Table 1). Among the different concentrations of IAA used for pretreatment of cuttings, the maximum percentage of rooting was obtained in cuttings treated with $0.57 \mathrm{mM}$ IAA. Among the different concentrations of IBA used for pretreatment, the maximum percentage of rooting was observed in cuttings treated with $0.49 \mathrm{mM}$ IBA. Moreover, the cuttings pretreated with $0.49 \mathrm{mM}$ IBA showed the highest root length as compared with other treatments. It is worth noting that higher doses of all three auxins tested further inhibited sprouting. In the case of IAA treatments, the inhibitions were more pronounced with $2.85 \mathrm{mM}$ IAA, where percentage of rooting decreased by $35 \%$ compared to cuttings treated with 0.54 mM IAA (Table 1). Collectively, application of NAA at $0.54 \mathrm{mM}$ brought the highest per cent rooting, numbers of roots, and acceptable root length. Therefore, $0.54 \mathrm{mM}$ NAA was used further for metabolic studies during the rooting process.

Table 1. Effect of different pretreatments of Indole-3-acetic acid (IAA), Indole-3-Butytric acid (IBA) and 1-Naphthylacetic acid (NAA) on rooting from single nodal cuttings of hybrid aspen (Populus tremula $\times$ P. tremuloides) after 3 weeks of growth in potting medium.

\begin{tabular}{cccc}
\hline Different Treatments & $\begin{array}{c}\text { \% of Rooting } \\
\text { (Mean } \pm \text { SE) }\end{array}$ & $\begin{array}{c}\text { No. of Roots/Cutting } \\
\text { (Mean } \pm \text { SE) }\end{array}$ & $\begin{array}{c}\text { Av. Root Length (cm) } \\
\text { (Mean } \pm \text { SE) }\end{array}$ \\
\hline Control $\left(\mathrm{H}_{2} \mathrm{O}\right)$ & $5.80 \pm 0.45 \mathrm{i}$ & $1.40 \pm 0.05 \mathrm{e}$ & $1.43 \pm 0.04 \mathrm{f}$ \\
IAA 0.57 mM & $35.48 \pm 0.63 \mathrm{e}$ & $2.72 \pm 0.23 \mathrm{c}, \mathrm{d}$ & $2.54 \pm 0.14 \mathrm{c}$ \\
IAA 1.71 mM & $19.13 \pm 0.38 \mathrm{~g}$ & $2.87 \pm 0.11 \mathrm{c}$ & $2.38 \pm 0.14 \mathrm{c}$ \\
IAA 2.85 mM & $15.11 \pm 0.78 \mathrm{~h}$ & $2.53 \pm 0.10 \mathrm{~d}$ & $2.01 \pm 0.13 \mathrm{~d}$ \\
IBA 0.49 mM & $42.10 \pm 0.67 \mathrm{~d}$ & $3.00 \pm 0.06 \mathrm{~b}, \mathrm{c}$ & $3.54 \pm 0.08 \mathrm{a}$ \\
IBA 1.47 mM & $34.34 \pm 1.38 \mathrm{e}$ & $3.16 \pm 0.10 \mathrm{~b}$ & $2.92 \pm 0.10 \mathrm{~b}$ \\
IBA 2.45 mM & $24.16 \pm 0.78 \mathrm{f}$ & $2.72 \pm 0.05 \mathrm{c}, \mathrm{d}$ & $2.45 \pm 0.04 \mathrm{c}$ \\
NAA 0.54 mM & $79.39 \pm 0.87 \mathrm{a}$ & $4.08 \pm 0.28 \mathrm{a}$ & $1.74 \pm 0.11 \mathrm{e}$ \\
NAA 1.62 mM & $63.73 \pm 1.09 \mathrm{~b}$ & $3.90 \pm 0.13 \mathrm{a}$ & $1.53 \pm 0.13 \mathrm{e}, \mathrm{f}$ \\
NAA 2.70 mM & $52.86 \pm 0.24 \mathrm{c}$ & $3.90 \pm 0.26 \mathrm{a}$ & $1.50 \pm 0.28 \mathrm{e}, \mathrm{f}$ \\
\hline
\end{tabular}

Mean of 30 nodal cuttings/treatment; repeated thrice. Means having the same letter in a column are not significantly different at $p<0.05$.

\subsection{Morphological and Anatomical Observations of Rooting Process of Cuttings}

The following description of the stem anatomy of hybrid aspen was based on transverse sections that were made from the basal part of cuttings, and it took 12 days until the appearance of ARs. The basal parts of the cuttings had a slanted cut surface where the NAA was applied (Figure 1a). The lower incision area started to become loose after 6 days and the cortex of the lower incision of some cuttings showed minor cracking. The basal position of cuttings began to enlarge; subsequently the outside of the periderm near the incision thickened slightly, swelled and formed many small white protrusions after 9 days, then the tips of these protrusions burst. Finally transparent and white young ARs erupted successively in all cuttings up to 12 days (Figure $1 \mathrm{~b}-\mathrm{c}$ ). After 3 weeks, the ARs grew to $3-5 \mathrm{~cm}$ (Figure 1d). 

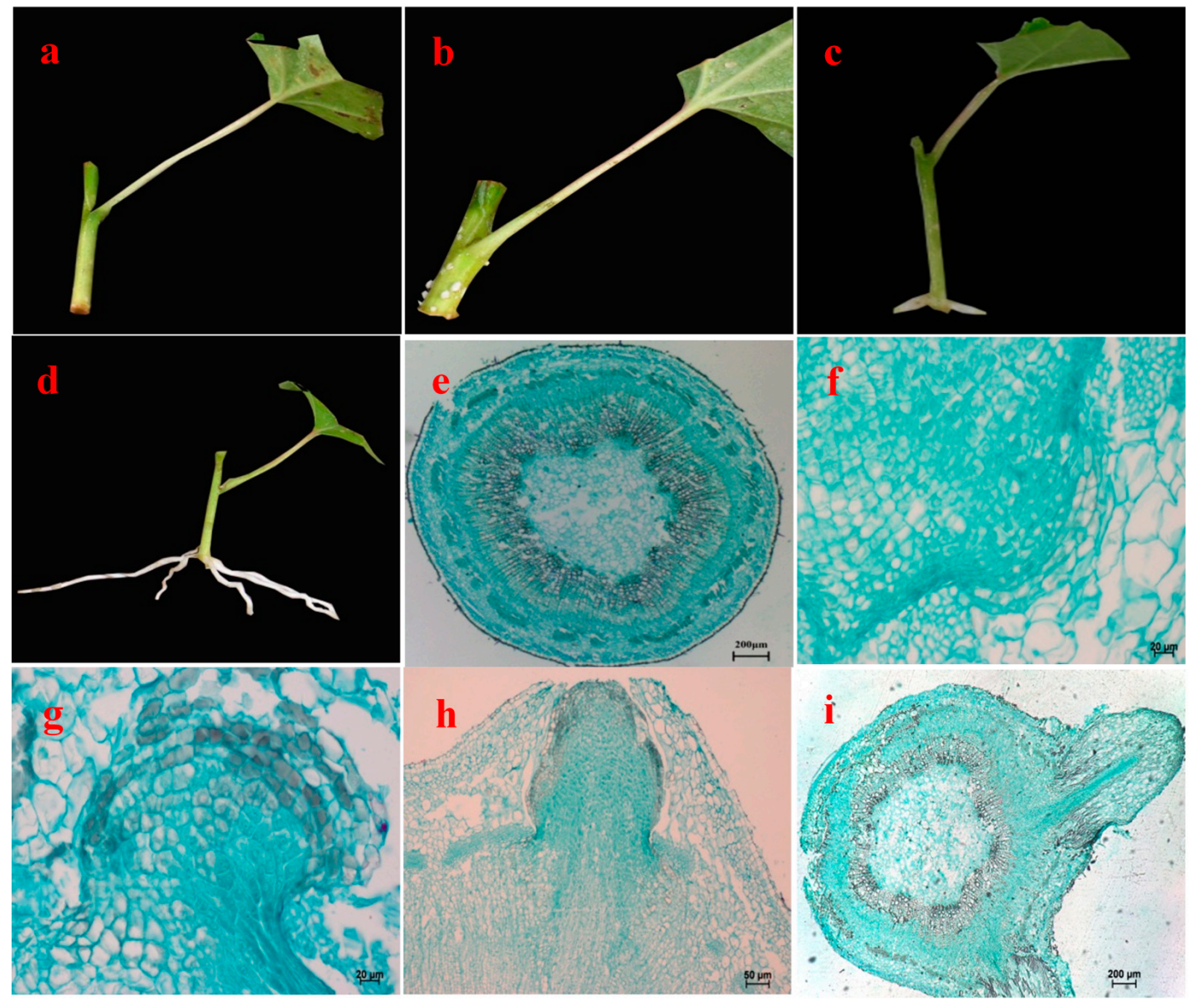

Figure 1. Morphological and anatomical observation on rooting of hybrid aspen (Populus tremula L. $\times$ P. tremuloides Michx.) cuttings. (a) Cutting 1 day after treatment with NAA; (b) White dot in cutting; (c) Adventitious root emerging from stem; (d) Adventitious root; (e) Stem transection; (f) Initial development of root primordium; (g) Continuous development of root primordium; (h) Adventitious root emerging from lenticel; Root primordium broken through cutex; and (i) Adventitious root elongating growth.

The stem is composed of periderm (including skin debris), cortex and secondary vascular tissues from the outside to the inside (Figure 1e). The cuttings first developed root primordia (Figure 1f), and parenchyma cells located in the junction of cambium and pith ray cells regained meristematic capacity. The parenchyma cells split and formed a parenchyma cell mass which showed larger nuclei, closely arranged, more clearly distinct from the surrounding cells. Root primordium cells near cambium cells stained darker and showed stronger divisibility, and gradually formed a group of smaller and darker-staining meristematic cells, constituting meristematic tissue mass (Figure 1g). The cells connected with the root primordia around the cambium layer differentiated faster, forming wedge-shaped AR primordia. These extended along the phloem-ray direction through the cortex and epidermis, ultimately extending outside the stems (Figure $1 \mathrm{~h}$ ). When they reached the periderm, the differentiation of AR vascular systems was completed, by which time distinct layers had emerged, forming a root cap, meristematic zone and an elongation zone (Figure 1i).

\subsection{Changes in the Level of Endogenous Hormones}

Higher levels of endogenous IAA were found in the cuttings treated with NAA in the early period of investigation (Figure 2A). At $6 \mathrm{~d}$ of treatment, the endogenous IAA content in the NAA-treated tissues was about 2.1 fold higher than that of controls. Thereafter, IAA gradually decreased, up to 
the control level at the end of treatment. In contrast, NAA treatment resulted in a gradual decrease in ABA level during the early period examined. Around the 6th day, the level of ABA reached a low peak (decreased by $42 \%$ ). In the later period investigated, the endogenous ABA content gradually recovered to control level (Figure 2B). There was a significant increase $(p<0.05)$ in endogenous ZR (zeatin riboside) level at $6 \mathrm{~d}$ treated (Figure 2C), and ZR content increased by $56 \%$ at $9 \mathrm{~d}$ in NAA-treated cuttings compared with controls. Regarding endogenous GA3 level, there were no changes before $6 \mathrm{~d}$ of NAA treatment. However, NAA significantly induced the endogenous GA3 content $(p<0.05)$ during 9 12 d examined (Figure 2D).
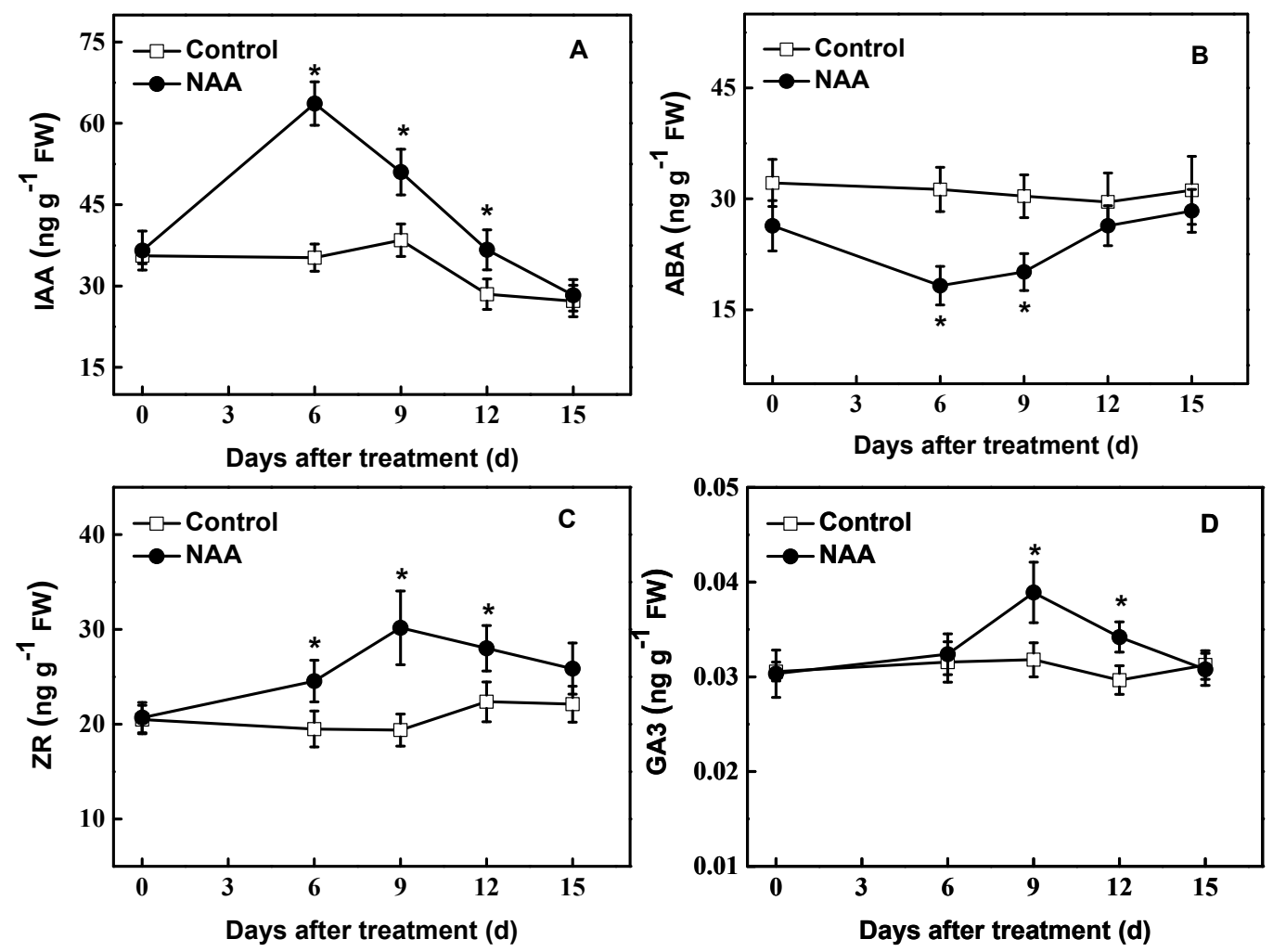

Figure 2. Endogenous levels of free IAA (A), ABA (B), Zeatin riboside (ZR) (C) and Gibberellic Acid (GA3) (D) in cuttings of hybrid aspen (Populus tremula L. $\times$ P. tremuloides Michx.) treated with NAA $(0.54 \mathrm{mM})$. Data are the means of at least five replicates with standard errors shown by vertical bars. * indicates significant differences at $p<0.05$.

\subsection{Biochemical Changes during Rooting}

In contrast with endogenous IAA levels, the IAAO activity in NAA-treated cuttings gradually decreased during the rooting period. At the end of the 9th day, the IAAO activity in the NAA-treated tissues had decreased by $25 \%$ compared with controls. The IAAO activity in NAA-treated cuttings increased gradually as the incubation was prolonged (Figure 3A). The POD activity in NAA-treated cuttings was also lower than that of controls during the test period. On the 9th $d$, there was a significant decline $(p<0.05)$ in POD activity in NAA-treated cuttings (67\% of the controls, Figure 3B). As the incubation time was prolonged, POD activity in NAA-treated cuttings increased, and the difference between NAA-treated and control tissues became less significant $(p<0.05)$. Unlike IAAO and POD, the PPO activity in NAA-treated cuttings was highest at 6th $d$ tested and then declined, but still higher than controls by the end of investigation (Figure 3C). 

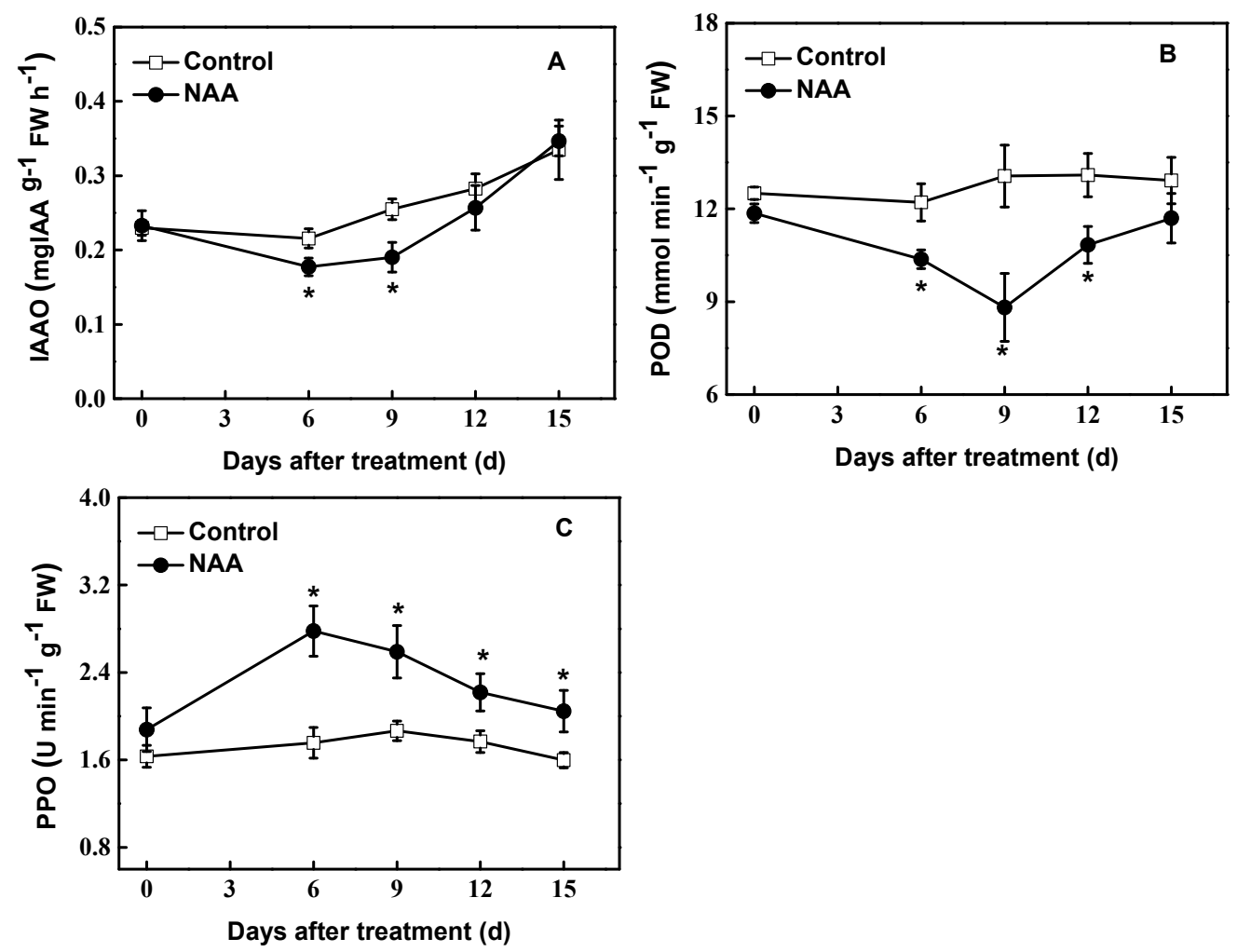

Figure 3. Effect of NAA on IAA-oxidase (IAAO) (A), polyphenol oxidase (PPO) (B) and decreased peroxidase (POD) (C) activity in hybrid aspen (Populus tremula L. $\times$ P. tremuloides Michx.) cuttings. Data are the means of at least five replicates with standard errors shown by vertical bars. * indicates significant differences at $p<0.05$.

\subsection{Gene Expression during Rooting}

Figure 4 shows the expression characteristics of POD1 and POD2 of cuttings exposed to $0.54 \mathrm{mM}$ NAA and water (Control) for 15 days, respectively. We found that expression of POD1 was down-regulated gradually in NAA-treated tissues at the early examined period. Up to $9 \mathrm{~d}$ tested, the expression of POD decreased by $53 \%$ compared to control plants. For POD2, consistent with POD activity, expression was significantly down-regulated, reaching $53 \%$ of controls at $12 \mathrm{~d}$ after NAA treatment (Figure 4).
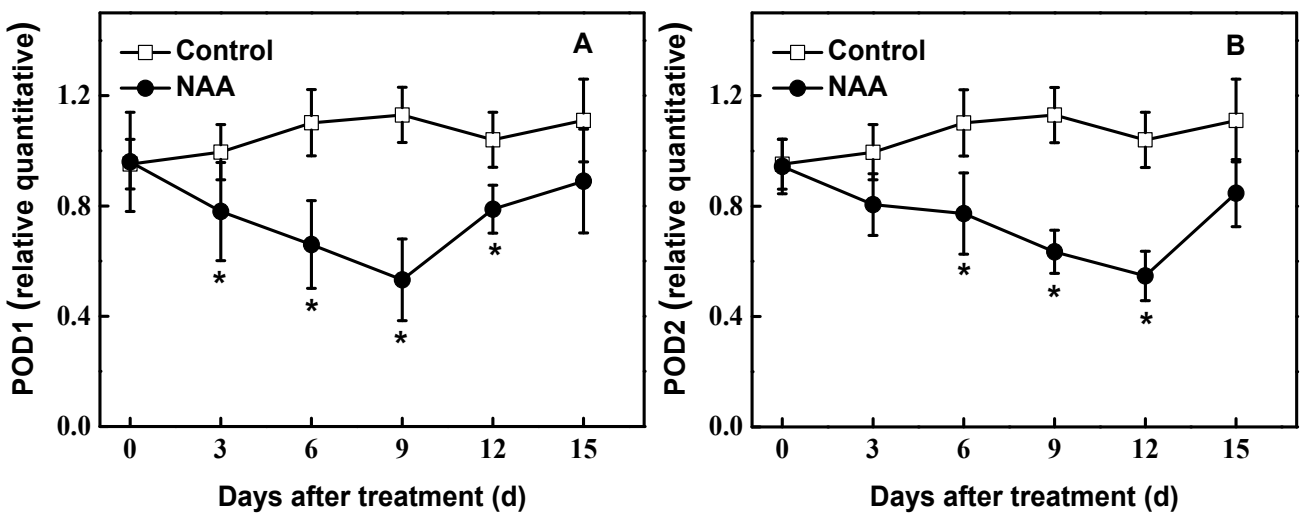

Figure 4. Effects of NAA on expression pattern of POD1 (A) and POD2 (B) in cuttings of hybrid aspen (Populus tremula L. $\times$ P. tremuloides Michx.) by qRT-PCR. Data are the means of at least five replicates with standard errors shown by vertical bars. ${ }^{*}$ indicates significant differences at $p<0.05$. 


\section{Discussion}

AR formation is often a limiting step for in vitro vegetative plant propagation programmes. The results of the present investigation indicate that stem cuttings of hybrid aspen (Populus tremula $\mathrm{L}$. $\times$ P. tremuloides Michx.) can be rooted effectively with the application of auxins (Table 1). Auxins are well known to play a significant role in stimulating AR from stem cuttings of tree species [22-25]. In addition to enhancing the rate of AR development, auxin application has been found to increase the number of roots initiated per rooted cutting in a variety of species [26,27]. Among the growth hormones, NAA at $0.54 \mathrm{mM}$ was found superior in terms of rooting rate and number of roots (per cutting) (Table 1) and hence it was recommended for rooting in hybrid aspen in our study. This is in line with the fact that a particular type of auxin is effective in enhancing rooting in a particular species [28]. A similar trend was also recently recorded for hormonal applications at different concentrations by Tiwari and Das [29], who reported that NAA is known to promote the expansion of roots in cuttings, thereby increasing the survival rate. It is worth noting that higher concentrations of auxin did not substantially produce a better result of rooting. For example, cuttings treated with $2.7 \mathrm{mM}$ NAA rooted worse than those with 0.54 or $1.62 \mathrm{mM}$ NAA (Table 1 ). The inhibitory effect caused by high exogenous auxin also occurs in other plants such as peach [30] and whip grass [31].

In the present study, NAA was also proved to be efficient by morphological and anatomical observation of the rooting process (Figure 1), with the same observable results as in apple microcuttings [32], Petunia hybrida [33] and Fuchsia hybrida cuttings [34]. On the other hand, the timing of root initiation may be critical in determining the optimal application time for hormones [35,36]. The AR primordia and root emergence were evident by 12 days in those cuttings treated with NAA (Figure 1) in our experiment, similar to the time of root emergence in cuttings of Eucalyptus globulus $\times$ E. maidenii [37] and of eucalypt hybrids [38].

Endogenous plant hormone levels in cuttings have been associated with root formation [39]. In the present study, NAA-treated cuttings showed an increase in endogenous IAA levels (Figure 2A). It is generally known that high concentrations of endogenous IAA have an important role in root initiation. Similar to our results, higher IAA contents were found in basal shoot parts of Ulmus glabra Huds [40] and Centaurium erythraea [41]. In addition to IAA content, we also found that the activity of IAAO was reduced markedly (Figure 3A), which might correspond to the rise in endogenous IAA levels, confirming previous results [42]. This suggests that the reduction of IAAO may be necessary for $A R$ formation [43]. In contrast to IAA, ABA content decreased after the cuttings were exposed to NAA treatment (Figure 3B). Generally, low concentrations of ABA positively affect callus growth and organogenesis, but high concentrations of ABA have a negative effect [44,45]. NAA treatment also induced the other endogenous hormones such as $\mathrm{ZR}$ and $\mathrm{GA}_{3}$ (Figure $2 \mathrm{C}, \mathrm{D}$ ) to different extents during the investigated period. The levels of the ZR increased during the rooting period, which was thought to be related to the formation of the cortex root [46]. Yan et al. [47] suggested that the level of GA3 was unchanged (or declined only slightly) in the initial cutting period, but increased markedly when calli were formed and root primordia differentiated. However, the changes in the levels of endogenous hormones were very complex, and many contrasting results were reported [41,48,49], a result most likely due to plant species, duration investigated, position of plants, environmental factors, etc. Furthermore, it can be conjectured that exogenously-applied auxin possibly alters the concentrations of endogenous hormones, and thus the original balance among endogenous hormones is replaced by the new balance beneficial to root formation [50].

Biochemical make-up plays a major role during rooting processes in plants [51]. Beyond the changes in IAAO activity mentioned above, PPO activity was increased in NAA-treated cuttings during the experimental phase (Figure 3C). The higher PPO activity might be associated with better rooting ability in treated cuttings, which was also consistent with data reported by Rout [31,51]. POD is known to be involved in auxin metabolism as well as lignification processes in the cell wall in the presence of phenol [52,53], and our data showed that the decrease of POD activity in NAA-treated tissues (Figure 3B) may cause greater accumulation of endogenous IAA, and enhance the induction of 
ARs in NAA-treated hypocotyls [43]. Moncousin et al. [54] reported that low POD corresponded to high IAA levels before the visible appearance of roots. The decrease of POD activity is correlated with a reduction of the transcript levels of POD1 and POD2 (Figure 4), indicating that the decrease in the activity of POD is most likely due to the inhibition of the de novo synthesis of POD1 and POD2 during AR induction. Klotz and Lagrimini [55] reported that NAA strongly suppressed POD gene expression by regulating the multiple auxin response elements within the POD gene promoter. Once POD gene expression is suppressed by NAA, which would result in the increased level of endogenous IAA, NAA worked together with endogenous IAA to stimulate cell division and elongation in treated tissues during the induction of AR in turn [56,57].

Consequently, the rooting was best with $0.54 \mathrm{mM}$ NAA in our study in general. The rooting response due to exogenous application of NAA was also reflected in the metabolic changes during AR formation in cuttings. Treatment with NAA increased the levels of endogenous IAA, ZR and GA3 but reduced the level of ABA. Higher activities of IAAO and lower POD and PPO activity in the NAA-treated cuttings were also found in cuttings with $0.54 \mathrm{mM}$ NAA.

Acknowledgments: This work was supported by Fundamental Research Funds for the Central Universities (2572015DA02), the National Natural Science Foundation of China (31170569, J1210053) and the Innovation Project of State Key Laboratory of Tree Genetics and Breeding (Northeast Forestry University).

Author Contributions: Xing Shun Song and Shao Peng Yan conceived and designed the experiments; Shao Peng Yan performed the experiments; Rui Hua Yang performed the microscopy; Fang Wang and Li Na Sun analyzed the data; Xing Shun Song wrote the paper.

Conflicts of Interest: The authors declare no conflict of interest.

\section{References}

1. Haus, S.; Gustavsson, L.; Sathre, R. Climate mitigation comparison of woody biomass systems with the inclusion of land-use in the reference fossil system. Biomass Bioenerg. 2014, 65, 136-144. [CrossRef]

2. Lutter, R.; Tullus, A.; Kanal, A.; Tullus, T.; Tullus, H. The impact of former land-use type to above- and below-ground $\mathrm{C}$ and $\mathrm{N}$ pools in short-rotation hybrid aspen (Populus tremula L. $\times$ P. tremuloides Michx.) plantations in hemiboreal conditions. For. Ecol. Manag. 2016, 378, 79-90. [CrossRef]

3. Paquette, A.; Messier, C. The role of plantations in managing the world's forests in the Anthropocene. Front. Ecol. Environ. 2010, 8, 27-34. [CrossRef]

4. Rytter, L.; Stener, L.G. Growth and thinning effects during a rotation period of hybrid aspen in southern Sweden. Scand. J. For. Res. 2014, 29, 747-756. [CrossRef]

5. Johansson, T. Biomass production of hybrid aspen growing on former farm land in Sweden. J. For. Res. 2013, 24, 237-246. [CrossRef]

6. Lutter, R.; Tullus, A.; Kanal, A.; Tullus, T.; Tullus, H. The impact of short-rotation hybrid aspen (Populus tremula L. $\times$ P. tremuloides Michx.) plantations on nutritional status of former arable soils. For. Ecol. Manag. 2016, 362, 184-193. [CrossRef]

7. Kristiansen, K.; Bredmose, N.; Nielsen, B. Influence of propagation temperature, photosynthetic photon flux density, auxin treatment and cutting position on root formation, axillary bud growth and shoot development in Schlumbergera 'Russian Dancer'. J. Hortic. Sci. Biotechnol. 2005, 80, $297-302$.

8. Leakey, R.R.B. Physiology of vegetative propagation. In Encyclopaedia of Forest Sciences; Burley, J., Evans, J., Younquist, J.A., Eds.; Academic Press: London, UK, 2004; pp. 1655-1668.

9. Fogaça, C.M.; Fett-Neto, A.G. Role of auxin and its modulators in the adventitious rooting of Eucalyptus species differing in recalcitrance. Plant Growth Regul. 2005, 45, 1-10. [CrossRef]

10. Gaspar, T.; Kevers, C.; Hausman, J.F. Indissociable chief factors in the inductive phase of adventitious rooting. In Biology of Root Formation and Development; Altman, A., Waisel, Y., Eds.; Plenum Press: New York, NY, USA, 1997; pp. 55-63.

11. Da Costa, C.T.; de Almeida, M.R.; Ruedell, C.M.; Schwambach, J.; Maraschin, F.S.; Fett-Neto, A.G. When stress and development go hand in hand: Main hormonal controls of adventitious rooting in cuttings. Front. Plant Sci. 2013, 4, 133. [CrossRef] [PubMed] 
12. Della Rovere, F.; Fattorini, L.; D’Angeli, S.; Veloccia, A.; Falasca, G.; Altamura, M.M. Auxin and cytokinin control formation of the quiescent centre in the adventitious root apex of Arabidopsis. Ann. Bot. 2013, 112, 1395-1407. [CrossRef] [PubMed]

13. Della Rovere, F.; Fattorini, L.; D'Angeli, S.; Veloccia, A.; Falasca, G.; Altamura, M.M. Arabidopsis SHR and SCR transcription factors and AUX1 auxin influx carrier control the switch between adventitious rooting and xylogenesis in planta and in in vitro cultured thin cell layers. Ann. Bot. 2015, 115, 617-628. [CrossRef] [PubMed]

14. Legué, V.; Rigal, A.; Bhalerao, R.P. Adventitious root formation in tree species: Involvement of transcription factors. Physiol. Plant 2014, 151, 192-198. [CrossRef] [PubMed]

15. Pacurar, D.I.; Perrone, I.; Bellini, C. Auxin is a central player in the hormone cross-talks that control adventitious rooting. Physiol. Plant 2014, 151, 83-96. [CrossRef] [PubMed]

16. Welander, M.; Geier, T.; Smolka, A.; Ahlman, A.; Fan, J.; Zhu, L.H. Origin, timing, and gene expression profile of adventitious rooting in Arabidopsis hypocotyls and stems. Am. J. Bot. 2014, 101, 255-266. [CrossRef] [PubMed]

17. Druege, U.; Franken, P.; Hajirezaei, M.R. Plant Hormone Homeostasis, Signaling, and Function during Adventitious Root Formation in Cuttings. Front. Plant Sci. 2016, 7, 381-394. [CrossRef] [PubMed]

18. Lodama, K.E.; du Toit, E.S.; Steyn, J.M.; Araya, H.T.; Prinsloo, G.; du Plooy, C.P.; Robbertse, P.J. Improving rooting of Lobostemon fruticosus L. cuttings with delayed auxin treatment. S. Afr. J. Bot. 2016, 105, 111-115. [CrossRef]

19. Cao, W.X.; Wang, Z.L.; Dai, T.B. Changes in levels of endogenous plant hormones during floret development in wheat genotypes of different spike sizes. Acta Bot. Sin. 2000, 42, 1026-1032.

20. Beffa, R.; Martin, H.V.; Pilet, P.E. In vitro oxidation of indoleacetic acid by soluble auxin-oxidases and peroxidases from maize roots. Plant Physiol. 1990, 94, 485-491. [CrossRef] [PubMed]

21. Li, Z.; Peng, Y.; Ma, X. Different response on drought tolerance and postdrought recovery between the small-leafed and the large-leafed white clover (Trifolium repens L.) associated with antioxidative enzyme protection and lignin metabolism. Acta Physiol. Plant 2013, 35, 213-222. [CrossRef]

22. Tchoundjeu, Z.; Ngo Mpeck, M.L.; Asaah, E.; Amougou, A. The role of vegetative propagation in the domestication of Pausinystalia johimbe (K. Schum), a highly threatened medicinal species of West and Central Africa. For. Ecol. Manag. 2004, 188, 175-183. [CrossRef]

23. Ludwig-Mu"ller, J. Indole-3-butyric acid in plant growth and development. Plant Growth Regul. 2000, 32, 219-230. [CrossRef]

24. Kochhar, V.K.; Singh, S.P.; Katiyar, R.S.; Pushpangadan, P. Differential rooting and sprouting behaviour of two Jatropha species and associated physiological and biochemical changes. Curr. Sci. 2005, 89, 936-939.

25. Ricci, A.; Rolli, E.; Brunoni, F.; Dramis, L.; Sacco, E.; Fattorini, L.; Ruffoni, B.; Díaz-Sala, C.; Altamura, M.M. 1,3-di(benzo[d]oxazol-5-yl)urea acts as either adventitious rooting adjuvant or xylogenesis enhancer in carob and pine microcuttings depending on the presence/absence of exogenous indole-3-butyric acid. Plant Cell Tissue Organ Cult. 2016, 126, 411-427. [CrossRef]

26. Mesen, F.; Newton, A.C.; Leakey, R.R.B. Vegetative propagation of Cordia allidora (Ruiz and Pavon) Oken: The effects of IBA concentration, propagation medium and cutting origin. For. Ecol. Manag. 1997, 92, 45-54. [CrossRef]

27. Palanisamy, K.; Ansari, S.A.; Pramod, K.; Gupta, B.N. Adventitious rooting in shoot cuttings of Azardirachta indica and Pongamia pinnata. New For. 1998, 16, 81-88. [CrossRef]

28. Puri, S.; Shamet, G.S. Rooting of stem cuttings of some social forestry trees. Int. Tree Crop J. 1988, 5, 63-69. [CrossRef]

29. Tiwari, R.K.S.; Das, K. Effect of stem cuttings and hormonal pre-treatment on propagation of Embelia tsjeriam and Caesalpinia bonduc, two important medicinal plant species. J. Med. Plants Res. 2010, 4, 1577-1583.

30. Tworkoski, T.; Takeda, F. Rooting response of shoot cuttings from three peach growth habits. Sci. Hortic. 2007, 115, 98-100. [CrossRef]

31. Yan, Y.H.; Li, J.L.; Zhang, X.Q.; Yang, W.Y.; Wan, Y.; Ma, Y.M.; Zhu, Y.Q.; Peng, Y.; Huang, L.K. Effect of Naphthalene Acetic Acid on Adventitious Root Development and Associated Physiological Changes in Stem Cutting of Hemarthria compressa. PLoS ONE 2014, 9, e90700. [CrossRef] [PubMed]

32. De Klerk, G.J.; Hanecakova, J. Ethylene and rooting of mung bean cuttings. The role of auxin induced ethylene synthesis and phase-dependent effects. Plant Growth Regul. 2008, 56, 203-209. [CrossRef] 
33. Ahkami, A.H.; Lischewski, S.; Haensch, K.T.; Porfirova, S.; Hofmann, J.; Rolletschek, H.; Melzer, M.; Franken, P.; Hause, B.; Druege, U.; et al. Molecular physiology of adventitious root formation in Petunia hybrida cuttings: Involvement of wound response and primary metabolism. New Phytol. 2009, 181, 613-625. [CrossRef] [PubMed]

34. Wróblewska, K. The influence of benzyladenine and naphthalene-1-acetic acid on rooting and growth of Fuchsia hybrida cuttings. Acta Sci. Polhortoru. 2013, 12, 101-113.

35. De Klerk, G.J.; Keppel, M.; Ter Brugge, J.; Meekes, H. Timing of the phases in adventitious root formation apple microcuttings. J. Exp. Bot. 1995, 46, 965-972. [CrossRef]

36. Mendes, A.F.S.; Cidade, L.C.; Otoni, W.C.; Soares-Filho, W.S.; Costa, M.G.C. Role of auxins, polyamines and ethylene in root formation and growth in sweet orange. Biol. Plant 2011, 55, 375-378. [CrossRef]

37. Schwambach, J.; Ruedell, C.M.; de Almeida, M.R.; Penchel, R.M.; de Araujo, E.F.; Fett-Neto, A.G. Adventitious rooting of Eucalyptus globulus x maidennii mini-cuttings derived from mini-stumps grown in sand bed and intermittent flooding trays: A comparative study. New For. 2008, 36, 261-271. [CrossRef]

38. Amanda, J.K.; Helen, M.W.; David, A.W.; Matthew, F.A.; Stephen, J.T. Improved Root Formation in Eucalypt Cuttings Following Combined Auxin and Anti-ethylene Treatments. J. Plant Sci. 2012, 7, 138-153.

39. Tsipouridis, C.; Thomidis, T.; Bladenopoulou, S. Rhizogenesis of GF677, Early Crest May Crest and Arm King stem cuttings during the year in relation to carbohydrate and natural hormone content. Sci. Hortic. 2006, 108, 200-204. [CrossRef]

40. Malá, J.; Gaudinová, A.; Dobrev, P.; Eder, J.; Cvirková, M. Role of phytohormones in organogenic ability of elm multiplicated shoots. Biol. Plant 2005, 50, 8-14. [CrossRef]

41. Trifunović-Momčilov, M.; Motyka, V.; DragićevićIvana, I.Č.; Petric, M.; Jevremović, S.; Malbeck, J.; Holík, J.; Dobrev, P.I.; Subotić, A. Endogenous phytohormones in spontaneously regenerated Centaurium erythraea Rafn. Plants Grown In Vitro. J. Plant Growth Regul. 2016, 35, 543-552. [CrossRef]

42. Vazquez, A.; Mato, M.C. Effects of hydroxybenzaldehydes on rooting and indole-3-acetic acid-oxidase activity in bean cuttings. Physiol. Plant. 1991, 83, 597-600. [CrossRef]

43. Liu, Z.H.; Hsiao, I.C.; Pan, Y.W. Effect of NAA on indoleacetic acid in hypocotyl cuttings of soybean during root formation. Bot. Bull. Acad. Sin. 1996, 37, 247-253.

44. Hoffmann-Benning, S.; Kende, H. On the role of Abscisic acid and Gibberellin in the regulation of growth in rice. Plant Physiol. 1992, 99, 1156-1161. [CrossRef] [PubMed]

45. Gaspar, T.; Kevers, C.; Penel, C.; Greppin, H.; Reid, D.; Thorpe, T. Plant hormones and plant growth regulators in plant tissue culture. In Vitro Cell. Dev. Bio.-Plant 1996, 32, 272-289. [CrossRef]

46. Liu, G.F.; Yang, C.P.; Qu, G.Z.; You, X.L. Dynamic changes of four endogenous hormones in the larch hybrid during cutting rooting. J. Northeast For. Univ. 2001, 29, 1-3. (In Chinese with an English abstract)

47. Huang, Y.; Ji, K.S.; Zhai, J.R. Relationship between rooting ability and endogenous phytohormone changes in successive continuous generation cuttings of Buxus sinica var. parvifolia, an endangered woody species in China. For. Stud. China 2007, 9, 189-197. [CrossRef]

48. Feng, D.L.; Huang, X.H.; Liu, Y.; Martin Willison, J.H. Growth and changes of endogenous hormones of mulberry roots in a simulated rocky desertification area. Environ. Sci. Pollut. Res. 2016, 23, 11171-11180. [CrossRef] [PubMed]

49. Hisano, H.; Matsuura, T.; Mori, I.C.; Sato, K. Endogenous hormone levels affect the regeneration ability of callus derived from different organs in barley. Plant Physiol. Biochem. 2016, 99, 66-72. [CrossRef] [PubMed]

50. Guo, X.F.; Fu, X.L.; Zang, D.K.; Ma, Y. Effect of auxin treatments, cuttings' collection date and initial characteristics on Paeonia 'Yang Fei Chu Yu' cutting propagation. Sci. Hortic. 2009, 119, 177-181. [CrossRef]

51. Rout, G.R. Effect of auxins on adventitious root development from single node cuttings of Camellia sinensis (L.) Kuntze and associated biochemical changes. Plant Growth Regul. 2006, 48, 111-117. [CrossRef]

52. Bernards, M.A.; Fleming, W.D.; Llewellyn, D.B.; Priefer, R.; Yang, X.; Sabatino, A.; Plourde, G.L. Biochemical characterization of the suberization-associated anionic peroxidase of potato. Plant Physiol. 1999, 121, 135-145. [CrossRef] [PubMed]

53. Quiroga, M.; Guerrero, C.; Botella, M.A.; Barcelo, A.; Amaya, I.; Medina, M.I.; Alonso, F.J.; de Forchetti, S.M.; Tigier, H.; Valpuesta, V. A tomato peroxidase involved in the synthesis of lignin and suberin. Plant Physiol. 2000, 122, 1119-1127. [CrossRef] [PubMed] 
54. Moncousin, C.; Favre, J.M.; Gaspar, T. Changes in peroxidase activity and endogenous IAA leves during adventitious rooting in vine cuttings. In Physiology and Biochemistry of Auxins in Plants; Kutacek, M., Bandurski, R.S., Krekule, J., Eds.; Academic Publishing: Prague, Czech Republic, 1988; pp. 331-337.

55. Lagrimini, L.M.; Vaughn, J.; Finer, J.; Klotz, K.; Rubaihayo, P. Expression of a Chimeric Tobacco Peroxidase Gene in Transgenic Tomato Plants. J. Am. Soc. Hort. Sci. 1992, 117, 1012-1016.

56. Aeschbacher, R.A.; Schiefelbein, J.W.; Benfey, P.N. The genetic and molecular basis of root development. Annu. Rev. Plant Physiol. Plant Mol. Biol. 1994, 45, 25-45. [CrossRef]

57. Chen, L.M.; Cheng, J.T.; Chen, E.L.; Yiu, T.J.; Liu, Z.H. Naphthaleneacetic acid suppresses peroxidase activity during the induction of adventitious roots in soybean hypocotyls. J. Plant Physiol. 2002, 159, 1349-1354. [CrossRef]

(C) 2017 by the authors. Licensee MDPI, Basel, Switzerland. This article is an open access article distributed under the terms and conditions of the Creative Commons Attribution (CC BY) license (http:/ / creativecommons.org/licenses/by/4.0/). 